\title{
The Anthropology Film Center
}

The Anthropology Film Center (P.O. Box 493, Santa Fe, New Mexico 87901) was established in 1966 to facilitate training, research, and communication among anthropologists who have recognized the possibilities of using film in their field. It will study the problems of film in anthropology, film recording and communication, techniques and methods, and its facilities include a library, research work space, and consultation services, directed by C. Warner Williams. An 'Anthropology-Film Newsletter' is to be the first release of a publications division.

\section{Rhodes House Library, Oxford: Guide to Manuscript Africana}

SiNCE its inception in 1928, Rhodes House Library in Oxford has been steadily building up its manuscript material. In addition, over the past five years the Oxford Colonial Records Project has deposited in the library considerable collections of diaries and private papers of former colonial administrators, most of whom served in Africa. Mr. Louis B. Frewer, the Librarian, has now compiled a summary guide to manuscript Africana in his custody. This is an up-to-date list of holdings and contains more than $\mathrm{r}, 200$ entries, territorially arranged. Material under official or personal restriction is so indicated; Rhodes House Library shelfnumbers have been appended to entries for all 'open' material. The list is available from the library at $f^{\mathrm{I}}(\$ 2.50)$ per copy, post free.

\section{'International Social Development Reviewn'}

International Social Development Review is published by the United Nations and takes the place of three of their earlier publications : the International Social Service Review, Housing, Building and Planning, and the Population Bulletin. The first issue contains the papers of a United Nations seminar held at Pittsburgh in November 1966 on the subject 'Development policies planned in relation to urbanization'. 'Urban growth and social development in Africa 'is discussed on pp. 39-47. Future issues of the Review will also have a theme or themes concerned with some aspect of development, particularly as it concerns the problems of developing countries.

\section{African National Unity: Northwestern University Prize}

Northwestern University Press and the Program of African Studies of Northwestern University announce an annual prize of $\$ 1,000$ for a work of non-fiction which contributes significantly to an understanding of national unity. It must provide new insights into factors and forces that aid or impair the cohesion of communities-local, regional, national, or international. The manuscript will be published by the Press. Its substantive content should be primarily - though not necessarily exclusively - concerned with African data. It may be a work of single or joint authorship, and the author or authors may be from any country. Before submitting a manuscript the author or authors should provide a précis of its content and a curriculum vitae. For 1969 this material should be submitted between I January and 30 June.

\section{German Dissertations on Africa for African Libraries}

During the International Conference on African Bibliography at Nairobi in December 1967 African librarians pointed out the difficulties of their libraries in obtaining copies of German dissertations concerning their countries. This problem was discussed at a meeting of German university librarians (Arbeitsgemeinschaft der Hochschulbibliotheken) and it was 